\title{
THEORETICAL AND PRACTICAL QUESTIONS OF THE PAYMENT CARD'S USE AS A PAYMENT METHOD IS RUSSIA AND ABROAD
}

\author{
${ }^{1}$ Alexander A. Galushkin, ${ }^{1}$ Valeriy V. Grebennikov, \\ ${ }^{2}$ Dmitriy A. Pashentsev, ${ }^{1}$ Igor M. Potashnik, ${ }^{3}$ Marat S. Shaykhullin, \\ ${ }^{1}$ Elena V. Maystrovich and ${ }^{1}$ Anastasiya S. Zhykovec \\ ${ }^{1}$ Department of Judicial Authority, Law-Enforcement and Human Rights Activity, \\ Peoples' Friendship University of Russia, Moscow, Russian Federation \\ ${ }^{2}$ Department of Civil Law, \\ Financial University under the Government of the Russian Federation, Moscow, Russian Federation \\ ${ }^{3}$ Department of State and Legal Disciplines, \\ International Institute of Informatization and Public Administration named in the honor of P.A. Stolypin, \\ Moscow Region, Russian Federation
}

Received 2014-08-04; Revised 2014-09-06; Accepted 2014-09-29

\begin{abstract}
In the present article authors analyze theoretical and practical questions of payment cards use in Russian Federation and abroad. Authors discuss historical and practical reasons for choosing payment cards as payment method, as well as reasons for different kinds of cards use. Authors pay discuss questions of payment card use in Russian Federation at the present time and analyze questions of such payment method use after the collapse of the Union of Soviet Socialist Republics (USSR). Author's discussion is based on the analyses of the current state of the Russian Federation banking system, its development and current state. During discussion authors use statistical data, including data on the largest banks in Russian Federation at the present time. In conclusion authors present ideas on possible ways of Russian Federation banking system future development in regard to payment cards (both debit and credit) use as a method of the non-cash payment implementation.
\end{abstract}

Keywords: Payment Cards, Credit Cards, Debit Cards, Payment, Purchase, Organization, Regulation

\section{INTRODUCTION}

Emergence of modern civil society is closely connected with the development of private property which became an incentive for the activity of modern globalized person. Interest of the person for manufacturing development and services providing is an effective base for the middle class emergence (Grudtsina and Galushkin, 2013). In the view of the above it is important to talk about payment card's use as a payment method of the present and questions of its development in the future.

In all developed countries of the modern civilized world payment cards have been used for a long time to pay for goods and services. Gradually this method of payments became not only popular, but actually the most common in the most countries of North America and Europe.

Obviously this is due to convenience of such payment method, which is reached by combination of favorable Peoples' Friendship University of Russia, Moscow, Russian Federation 
terms of customer service, quality of services, increased safety and increased payment culture.

\section{MATERIALS AND METHODS}

In the present article authors present summery of conducted research, where research problem was formulated, a good empirical base accumulate, an opportunity to focus on the research process and to draw conclusions that would reflect the real situation in the best possible way using: Introductionhypothesis, deduction-predictions, observation-nest of predictions, etc. was given.

\section{RESULTS}

Cards differ both in purpose of use and technical characteristics. Types of cards include: Payment cards, club cards, discount cards, identity cards.

For the purposes of this article we are talking only about payment cards.

Payment cards are issued by banks and other credit institutions. Technically cards are issued in connection to one of the payment card systems.

Currently, most popular payment card systems include: Visa, Master Card, Diner Club, American Express.

Commonly payment cards are divided in large groups: Classic (standard), electronic, gold and platinum. (Galushkin, 2014).

Apart from the global payment system, payment cards may be connected to national system, local payment system.

Technically payment card's characteristics may include contact card and/or proximity, may contain a barcode, magnetic stripe, a chip, or may be combined (magnetically-chip), or may not have any digital information carriers.

After the Soviet Union' collapse, Russian Federation started to integrate into the globalized world and implement many of the proven technologies. This lead to many positive consequences, among which was introduction of new services and products (including payment card systems).

Past few years showed that transactions with the use of plastic cards became very popular among population of Russian Federation. This is obviously due to many advantages of payment cards over cash payments. Amongst advantages we can point out such as lack of need to store and transport cash in person, mandatory issuance of the payment receipt to the payee, no need for wait for banknotes authentication.
Due to the above reasons payment cards are convenient to use for small purchases: From chewing gum, fruit and vegetables, etc., as well as for average price purchases: Appliances, travel packages, air tickets, etc and for many large purchases also. In some cases holders of premium payment cards pay for such expensive items as cars, real estate, etc.

Unfortunately, while Soviet Union existed and for many years after it collapsed banking sector in Russian has developed very slowly. Banking services were provided at a very low quality level and did not comply with most international standards. At the same time, rates and fees were significantly higher than for similar services in other developed countries.

With the gradual stabilization of Russian economy and positive changes in domestic banks quality policy, combined with start of foreign banks in Russian Federation operation quality of service provided on the domestic market increased and started to approach international level. A great number of citizens started to trust their money to new banks.

Previously citizens could deposit funds in banks only on the saving accounts of the certain bank, now citizens of the Russian Federation and citizens of other countries, as well as stateless persons and legal entities, their branches and representatives legally residing and/or operating on the territory of the Russian Federation got considerable freedom in the choice of both the bank in which they want to deposit their money and the most convenient banking products for them. Many banking products are now associated with the payment card issuance.

With the opportunity to open an account with the payment card associated to it both private and corporate clients got a lot of new opportunities to conduct many financial actions easier. For example legal entities got new opportunity to make non-cash payments without the use of old transfer schemes (by preparing payment orders), but rather paying with a payment card. In this tupe of payment, payment cards are usually used to pay for goods for the administrative purposes, pay during business travel.

Great popularity in Russian Federation are now choosing to get payroll on the payment cards. In accordance with Article 136 of the Labor Code of the Russian Federation (RF, 2001) wages must be paid no less often than every two weeks, on the day set by internal regulations of the organization, collective agreement and/or the employment contract. 
At the same time, in the case of the classic method of wage payment an organization would need to prepare a lot of documents, order cash in banks for the certain day, withdraw and transport cash, prepare the place for wages payment to the workers and make immediate payment of wages.

It is obvious that such actions take a disproportionate amount of time that in a modern market economy simply cannot be effectively and profitably.

At the same time payroll to payment cards allow almost immediately to debit the account of the employer and to transfer money into employee's account by the prearranged assignments. There is no need for employee to stand in the queue for salary and to the employer no need to carry money and thus decrease risk of robbery and theft.

\section{DISCUSSION}

Unfortunately in the minds of most Russian citizens payment cards are often associated with debit (prepaid) cards.

Meanwhile international practice of issuing payment cards shows that in developed countries, most issued payments cards are credit cards.

In North America many people buy goods and pay for services with credit cards.

As of July 9, 2014 in the USA the total number of credit cards in use is $1,895,834,000$ and the total number of credit card holders is $199,800,000$ SB (2014c). This meant that in average each citizen of USA that has a credit card actually have almost 10 credit cards.

Current as of April 2014 "The average US household credit card debt stands at $\$ 15,191$, the result of a small number of deeply indebted households forcing up the numbers. Based on an analysis of Federal Reserve statistics and other government data, the average household owes $\$ 7,087$ on their cards; looking only at indebted households, the average outstanding balance rises to $\$ 15,191$. Here are statistics, trends, studies and methodology behind the average U.S. household debt". (NerdWallet, 2014)

As of July 12, 2014 the total U.S. credit card debt is \$793.1 Billion, an average household debt is 54,000 . The average balance per open credit card is $\$ 1,157$ (SB, 2014a).

Practice of the past 5-10 years shows that in Russian Federation the number of issued payment cards in general increased.

However mostly these are the debit cards and only a small number of payment cards are credit cards.

In the 2000s in Russian Federation become increasingly popular gray schemes of the payment cards use. Usually these cards were issued abroad (mainly in offshore banks).

Basically, some of the foreign banks that open accounts can open it to anyone, including a non-citizen of this country. In Russian Federation became especially popular banks of such countries as Switzerland, Cyprus, British Virgin Islands, Panama and several other states in view of their very liberal legislation.

Some of these country's banks do not even require a person to come to the bank to open an account or to confirm passport data. Issued payment card is sent by mail.

Use of such payment cards became especially popular for: Bribing officials (there is no money handing in person, only a nameless plastic card) as a means of withdrawing funds after laundering or tax evasion and withdrawal of funds abroad, to finance criminal activity, including terrorist activities (when cash is transferred abroad for a certain plastic card, usually issued abroad and cash withdrawn already in Russian bank on the territory of Russian Federation), for the illegal business activities conduct, particularly in the information and telecommunications network Internet (when cash is obtained by means of electronic payment systems and transferred to the payment card issued by a foreign bank).

In spite of the fact that legal regulation of banking activities, as well as issues of suppression of criminal activities with the use of plastic cards and drug use is not the subject of this study, since the vastness of the subject is not possible to completely ignore some of these aspects.

Despite the wide variety of researches in this area, subject is constantly enriched by the new practice, enriched with new products and services associated to them.

For example in 2014some of the Russian banks were disconnected from payment systems Visa and MasterCard.

This fact once again warmed state, public and corporate interest in the establishment of the Russian Federation's fully multifunctional national payment system.

Even though there is currently couple of hundreds of banks in Russian Federation only some of them are actually big and got a real weight on the market.

Let's take a look at the top 10 banks in Russian Federation.

As of July 24, 2014 rank of the longest banks in Russian Federation include:

- Sberbank

- VTB

- Gazprombank

- VTB-24 
- Bank of Moscow

- Rosselkhozbank

- Alfa Bank

- Financial Corporation Otkritie (previously Nomos Bank)

- Unicredit

- National Clearing Centre

All of the above banks have different history of creation and operation, however all of them are most popular in Russian Federation and their products are most popular among citizens. Most payment cards in Russian Federation are issued by these banks.

When we discuss questions of the payment card's use as a payment method it is important to talk about the security questions.

Payment cards, like any other cards are also subject to theft. There is no available to authors reliable statistics on the credit cards fraud in Russian Federation. So for statistical purposes let's take a look at credit card statistics in USA.

As of July 12, 2014" Percent of Americans who have been victims of credit card fraud is $10 \%$. Median amount reported on credit card fraud is $\$ 399$. Total amount of credit card fraud worldwide is $\$ 5.55$ Billion.

Initial point of contact for fraud include:

- $\quad$ Email $48 \%$

- Internet Website $12 \%$

- Telephone $10 \%$

- Other 17\% (SB, 2014b)

In Russian Federation payment cards fraud is also common. However cards that are being subject to fraud are usually debit cards. This is due to the fact that debit cards are more common in Russian Federation than credit cards.

Approach of different banks in cases when their clients suffer from fraud differ from bank to bank, however in general many banks follow the client oriented approach and thoroughly investigate each fact.

In past couple of years a new type of fraud appeared. Some companies that sell online (for example tickets) add additional services and withdraw money from the payment card of the client without any authorization or consent.

The idea of such organizations is that the amounts they withdraw is too little to lead to criminal liability, clients will not understand the difference, if clients would ask to return the money they would be proposed to cancel the ticket soon before the event and return all money, however not the difference.

\section{CONCLUSION}

Payment cards are becoming one of the most popular methods of payment in Russian Federation.

Payment cards are being issued by many banks worldwide, however most issued payment cards are associated to one of the largest multinational financial services corporations like Visa, MasterCard and other, however some are associated to national and/or regional corporations holding own alternative payment system.

For many reasons organizational questions of rendering such services are dependent on laws of country where corporation owning the payment system headquartered.

In the modern globalized world, where application of technologies is possible through country boarders many of such laws are becoming only a political instrument.

For these reason authors believe that norms of international law, regulating questions of multinational financial services corporation activities should be developed and implemented.

Furthermore, authors believe that a number of mechanisms should be implemented in Russian Federation.

Internal mechanisms of information telecommunication and transaction providing systems should be made autonomous and be able to work nationally independently from the worldwide system.

Such practice is not new, a number of countries already developed and implemented there national systems. One of the best examples is Canada, whose banking system is considered to be one of the best in the world.

\section{REFERENCES}

Galushkin, A.A., 2014. Modern prastic card types and methods of protection. Person. State. Law, 2: 12-12.

Grudtsina, L.J. and A.A. Galushkin, 2013. Questions of modern civil society development in Russian Federation. World Applied Sci. J., 25: 790-793. DOI: 10.5829/idosi.wasj.2013.25.05.1438

NerdWallet, 2014. American Household Credit Card Debt Statistics: 2014. NerdWallet, Inc.

RF, 2001. Labor code of the Russian Federation. Russian Federation. NATLEX.

SB, 2014a. Credit card debt statistics. Statistic Brain.

SB, 2014b. Credit card fraud statistics. Statistic Brain.

SB, 2014c. Credit card ownership statistics. Statistic Brain. 